\title{
Staphylococcus aureus: a threat to food safety
}

\author{
Staphylococcus aureus: uma ameaça à segurança alimentar \\ Staphylococcus aureus: una amenaza para la seguridad alimentaria
}

Received: 10/23/2021 | Reviewed: 10/30/2021 | Accept: 11/03/2021| Published: 11/06/2021

\author{
Weslley de Souza Paiva \\ ORCID: https://orcid.org/0000-0002-2022-5659 \\ Universidade Federal do Rio Grande do Norte, Brazil \\ E-mail:weslley.paiva.093@ufrn.edu.br \\ Francisco Ernesto de Souza Neto \\ ORCID: https://orcid.org/0000-0002-7413-2351 \\ Faculdade Nova Esperança de Mossoró, Brazil \\ E-mail: fernestosn@gmail.com \\ Laís Lacerda Brazil de Oliveira \\ ORCID: https://orcid.org/0000-0003-2814-3575 \\ Universidade Federal do Ceará, Brazil \\ E-mail: laisBrazil@ufc.br \\ Maria Gilnara Lima Bandeira \\ ORCID: https://orcid.org/0000-0002-4690-7623 \\ Universidade Federal do Ceará, Brazil \\ E-mail: gilnarabandeira@gmail.com \\ Erika de Souza Paiva \\ ORCID: https://orcid.org/0000-0002-7491-9242 \\ Universidade Federal do Piauí, Brazil \\ E-mail: drerikapaiva@ hotmail.com \\ Anabelle Camarotti de Lima Batista \\ ORCID: https://orcid.org/0000-0002-0905-6911 \\ Universidade Federal da Paraíba, Brazil \\ E-mail:bellecamarotti@gmail.com
}

\begin{abstract}
Foodborne Diseases (FBD) affect millions of people worldwide. They are caused mainly by bacteria of the genus Staphylococcus, mainly Staphylococcus aureus. Among these, some produce enterotoxins that are resistant to high temperatures and can contaminate various types of foods such as milk and dairy products, in addition to meat products and others. For these reasons, it is necessary to study $S$ aureus and Staphylococcal Enterotoxins (SE), which are the main causes of FBD, and the development of actions and new products that maintain the health of food, especially milk, daity dirivates and meat products, in order to reduce contamination. In addition to the study of more efficient techniques for detecting these contaminating agents. Among these techniques, molecular techniques stand out, which currently have been shown to be increasingly sensitive and specific. In general, the association of good hygiene practices and molecular detection techniques are fundamental for maintaining food health, avoiding losses in the industry and serious health problems.
\end{abstract}

Keywords: Foodborne diseases; Food poisoning; Toxins; Good handling practices.

\section{Resumo}

As Doenças Transmitidas por Alimentos (DTAs) afetam milhões de pessoas em todo mundo. Elas são causadas principalmente por bactérias do gênero Staphylococcus, principalmente Staphylococcus aureus. Dentre esses, alguns produzem enterotoxinas que são resistentes a altas temperaturas, podendo contaminar vários tipos de alimentos como leite e derivados, além de produtos cárneos e outros. Por essa razão são necessários estudos de boas práticas de manipulação, higiene e fabricação na indústria de alimentos, a fim de evitar grandes perdas econômicas e graves problemas de saúde humana. Como consequência desses estudos, técnicas de detecção do microorganismo e também de suas toxinas vêm evitando que alimentos contaminados tenham seu processo interrompido ainda durante a cadeia produtiva. Dentre essas técnicas destacam-se as moleculares, as quais, atualmente, têm se mostrado cada vez mais sensíveis e especificas. De maneira geral, a associação de boas práticas de higienes e de técnicas moleculares de detecção são fundamentais para a manutenção da sanidade alimentar, evitando prejuízos na indústria e graves problemas de saúde.

Palavras-chave: Doenças transmitidas por alimentos; Intoxicação alimentar; Toxinas; Boas práticas de manipulação. 


\section{Resumen}

Las enfermedades transmitidas por alimentos (ETA) afectan a millones de personas en todo el mundo. Son causadas principalmente por bacterias del género Staphylococcus, principalmente Staphylococcus aureus. Entre estos, algunos producen enterotoxinas que son resistentes a las altas temperaturas y pueden contaminar diversos tipos de alimentos como la leche y los productos lácteos, además de los productos cárnicos y otros. Por ello, son necesarios estudios de buenas prácticas de manipulación, higiene y fabricación en la industria alimentaria para evitar grandes pérdidas económicas y graves problemas de salud humana. Como resultado de estos estudios, las técnicas de detección del microorganismo y también de sus toxinas han estado evitando que los alimentos contaminados tengan su proceso interrumpido durante la cadena de producción. Entre estas técnicas destacan las moleculares, que, en la actualidad, han demostrado ser cada vez más sensibles y específicas. En general, la asociación de buenas prácticas de higiene y técnicas de detección molecular son fundamentales para el mantenimiento de la salud alimentaria, evitando pérdidas en la industria y graves problemas de salud.

Palabras clave: Enfermedades transmitidas por alimentos; Intoxicación alimentaria; Toxinas; Buenas prácticas de manejo.

\section{Introduction}

One of the biggest health problems worldwide is infection by eating contaminated food, which can lead to foodborne diseases - FBD (Montanhini \& Hein, 2013). One of the most common forms of FBD is gastroenteritis caused by consuming food containing microbial toxins. Among food poisoning, the highlights are those caused by Staphylococcus aureus, which are responsible for outbreaks of food poisoning worldwide (Goulart et al., 2016).

As the main cause of these intoxications by $S$. aureus we have Staphylococcal Enterotoxins (SEs), which are singlechain and globular proteins with molecular weight ranging between 22 and $29 \mathrm{kDa}$, soluble in water and in saline solutions (Hennekinne et al., 2013). Many of these are resistant to high temperatures and are not inactivated by heat sterilization processes. In men they are responsible for gastroenteritis, enterocolitis, diarrhea, staphylococcal food poisoning, and other diseases. For these diseases, the severity of the contamination depends on factors such as the amount of contaminated food that was ingested, the amount of toxins present in the food ingested and the patient's previous health status (Sá et al., 2012).

In situations where the bacteria is also present inside the host during the intoxication process, the disease can be aggravated by mechanisms of resistance to antibiotics. Some strains of $S$. aureus can carry antibiotic resistance genes, including blaZ and mecA. BlaZ is a gene that promotes resistance to drugs in the class of $\beta$-lactamase-non-stable agents and $m e c A$ selects resistance to other drugs such as oxacillin and methicillin. The ability to spread this resistance to other microorganisms gives $S$. aureus great importance in the food industry, so that it is not present in the production chain (Aragão et al., 2019).

In view of the harmful effect that contamination of food by S. aureus can cause in humans, it is essential that good practices of handling and hygiene are implemented throughout the food industry. In addition to conducting studies of modern techniques able to identify, quickly and specifically, pathogens that cause FBD, thus avoiding economic and health problems.

\section{S. aureus and its importance in the food industry}

\subsection{Milk and its derivatives}

Milk is a product of animal origin that has a high biological value, being the most complete food in the human diet, especially in the early stages of life (Cruz et al., 2017). It is mainly composed of water, proteins, fats, carbohydrates, minerals, in addition to fractions of vitamins, and therefore ensuring its quality is a matter of public health (Becker et al., 2010).

Contamination by $S$. aureus affects milk composition, either by the extracellular action of enzymes or by the enzymatic mechanisms triggered by the animal's innate immune response to the pathogen (Le Roux et al., 2003). The main changes are in the protein composition, as well as in the milk fat rate. In addition to the decrease in milk production and an increase in expenses with medicines and veterinary assistance (Motta et al., 2011). 
In dairy cattle, contamination by $S$. aureus one of the mastitis cause, a condition that promotes an inflammatory process in the mammary gland. Due to its high incidence, mastitis is considered the most relevant disease in dairy cattle and your products (Tozzetti et al., 2008).

In humans, contamination by SEs further gastrointestinal disorders, caused by food poisoning that can occur by ingesting up to $20 \mathrm{ng}$ of the toxin. Ingestion of these SEs can cause food poisoning characterized by vomiting, nausea, diarrhea, abdominal pain, with an incubation period of one to six hours after eating the contaminated food (Hennekinne et al., 2013). The duration of the condition is usually short (24 to 48 hours) and the patient's recovery can occur from one to three days (Holmberg \& Blake, 1984).

Order to reduce the high prevalence of $S$. aureus in the dairy industry, a program for the control of microorganisms for milk and dairy products was created, which is based on the correct management of milking (disinfection of post-milking ceilings and milking materials), treatment of all clinical cases, in addition to segregation or disposal of animals with chronic mastitis, for example (Santos \& Fonseca, 2006; Denis et al., 2009). Other techniques are shown to be very effective in combating outbreaks of contamination: vaccination (Detillex et al., 2009) and genetic improvement of animals (Ferreira \& Simm 2012).

\subsection{Meat products}

The complex nutritional composition, the high water activity and the $\mathrm{pH}$ close to neutrality make beef an excellent medium for the growth of microorganisms. These, in high concentration, can cause deterioration and risk to the consumer's health (Marchi et al., 2012).

Among meat products, ground meat is a product that is easily contaminated with $S$. aureus due to excessive handling (Akbas \& Kokumer, 2015). As a result, S. aureus can be an important indicator of personal hygiene and the evaluation of industrial sanitation programs (Zhang et al., 2018).

In this type of food, another concern is the formation of bacterial biofilms by S. aureus (Fuster-Valls et al., 2008), considering that washing and sanitization may not guarantee the complete elimination of biofilms from this microorganism. Biofilms, when formed, act as sources of constant contamination, releasing cells from the bacteria that constitute them, which can compromise the microbiological quality of food (Lima et al., 2004).

Given the fact that the consumption of meat products is high worldwide, good practices in handling and manufacturing food are very important, in order to have no level of contamination by S. aureus, ensuring good quality of food and consequently maintaining consumer health.

\section{Safe Food Handling Practices}

Due to their ability to inhabit living surfaces, strains of $S$. aureus, throughout human history, have been repeatedly reported for their presence in various food products and also in epidemiological studies of food poisoning outbreaks involving different regions of the world (Erhabor et al., 2019; Liyanage, 2020; Galo et al., 2020). The basis of most reports of food poisoning by S. aureus is closely related to undue or scarce good hygiene practices, whether due to the handler's malpractice or negligence, or even to the work environment offered to them (Martin et al., 2004).

In view of this growing global problem, it is seen that during the last few years there has been a continuous cooperation between scientific bodies of great relevance such as the British Standards Institution (United Kingdom) and the Food and Drug Administration (United State of America). Both seeking a consistent exchange of information, based on experiments that improve safe practices in food handling, thus avoiding high numbers of food poisoning. Through these 
efforts, these and other organizations were able to issue recommendations for better detection and identification of $S$. aureus and its enterotoxins, in addition to procedures that guarantee food safety, such as Hazard Analysis and Critical Point Control (HACCP) (Martin et al., 2004).

\subsection{HACCP System}

The HACCP system consists of three stages main points: the first determine the danger to which the consumer may be subjected; the second, identifies the critical control points, ensuring safe management of the danger; and the third, monitoris the the ensure efficiency in the operation of critical control points. This is a well-known system and used in the food industry sector, because through its determinations it is possible to guarantee the food security of the various products sold (Martin et al., 2004).

To ensure this safety, the food industry considers some critical control points, such as:

- Use of raw materials containing minimum levels of $S$. aureus;

- Use of treatments to reduce the microbial load S. aureus;

- Use of additives or low temperature to prevent the multiplication of S. aureus during handling and storage;

- Use of hygienic handling to prevent the reintroduction of S. aureus;

All of these points can be achieved by controlling the factors that influence the proliferation of $S$. aureus, such as temperature, $\mathrm{pH}$, water activity, and sodium chloride concentration in the product (Basti et al., 2007). Constant monitoring, through microbiological analysis, is essential, as there is the possibility that the treatments used to ensure the elimination of the dangers caused by the microorganism are partially effective, since Staphylococcus enterotoxins are more resistant to treatments than cells producers of these (Basti et al., 2007).

Thus, the discovery and use of adjuvants to these treatments is necessary and imminent. An adjuvant widely used by scientists are essential oils, as they have a satisfactory efficacy trajectory. This is possible to see through the experiments described in literature (Chen et al., 2008; Ghani et al., 2018).

\subsection{Effective treatments against $S$. aureus}

\subsubsection{Essential Oils}

Studies with essential oils are constant, always bringing important results, as in the studies by Ghani and collaborators (2018), who described the effect of the antimicrobial activity of soluble soybean polysaccharide (SSPS) films on fresh meat (Pranoto et al., 2005). Through its results it was possible to detect that SSPS films containing 0.6\% nanoemulsion (based on the concentration of cinnamon essential oil) had effects on gram-positive bacteria (Staphylococcus aureus and Streptococcus pyogenes). SSPS films containing $0.8 \%$ nanoemulsion had antimicrobial effects on gram-positive and gram-negative bacteria.

In addition to oils, another adjuvant widely used for food control and safety is antimicrobial peptides, which are fragments of proteins present in the innate immune system of invertebrates and vertebrates as host defense molecules. These can be used on several fronts, mainly in the incorporation at the moment of production of the food itself as well as in the production of its packaging (Damasceno et al., 2014; Santos et al., 2018).

\subsubsection{Bioactive Molecules}

Active packaging materials containing antimicrobial peptide have emerged as a promising approach to delay food spoilage and increase food security (Pola et al., 2016). One of the main microbial peptides used is nisin, which is produced by the bacterium Lactococcus lactis. Using this peptide, aiming at the coating of coalho cheese, the experiment by Damasceno et 
al. (2014) generated results that demonstrated the efficiency of the nisin coating, since it inhibited the growth of positive coagulase Staphylococcus, in detriment to the control cheese (without coating), increasing its shelf life (Damasceno et al., 2014).

\subsubsection{Chemical Treatments}

As an alternative to the treatments and adjuvants to control S. aureus, a study was recently published using a Citrox solution, composed of $18 \mathrm{~g}$ of citric acid, $18 \mathrm{~g}$ of malic acid and $5 \mathrm{~g}$ of ascorbic acid in $100 \mathrm{ml}$ of water, with a $\mathrm{pH}$ of approximately 2.7. Concentrations of $1 \%$ and $2 \%$ of this solution were used to evaluate the inhibitory potential against methicillin-resistant S. aureus (MRSA) in chicken fillet. As a result, the inhibition of MRSA in the chicken fillet was noticed, with the total viable count gradually decreasing in the first three days of storage (Yehia et al., 2020).

The constant discovery of resistance mechanisms by bacteria, requires that science constantly seek new measures of microbial control, especially related to the food industry. When carrying out good hygiene, handling and manufacturing practices associated with the manipulator's day-to-day life, it is critical to reduce food poisoning, in addition to the imminent and constant need for new techniques that detect staphylococcal enterotoxins, in order to avoid the increase in foodborne diseases.

\section{Molecular Techniques for Identification of Staphylococcal Endotoxins}

In order to diagnose staphylococcal food poisoning, in general, it is necessary to know that SE (Staphylococcal Enterotoxins) are generally detectable in food when the S. aureus count exceeds $10^{5} \mathrm{CFU} / \mathrm{mL}$ or $\mathrm{g}$ of food (Wong \& Bergdoll, 2002). The biggest problem in identifying SE in food is the small amount that is found (Lancette \& Bennett, 2001). To improve the characterization of SE, several techniques have been integrated into the diagnostic and research strategy (Table $1)$.

Table 1 - Techniques used to identify Staphylococcal Endotoxins (SE).

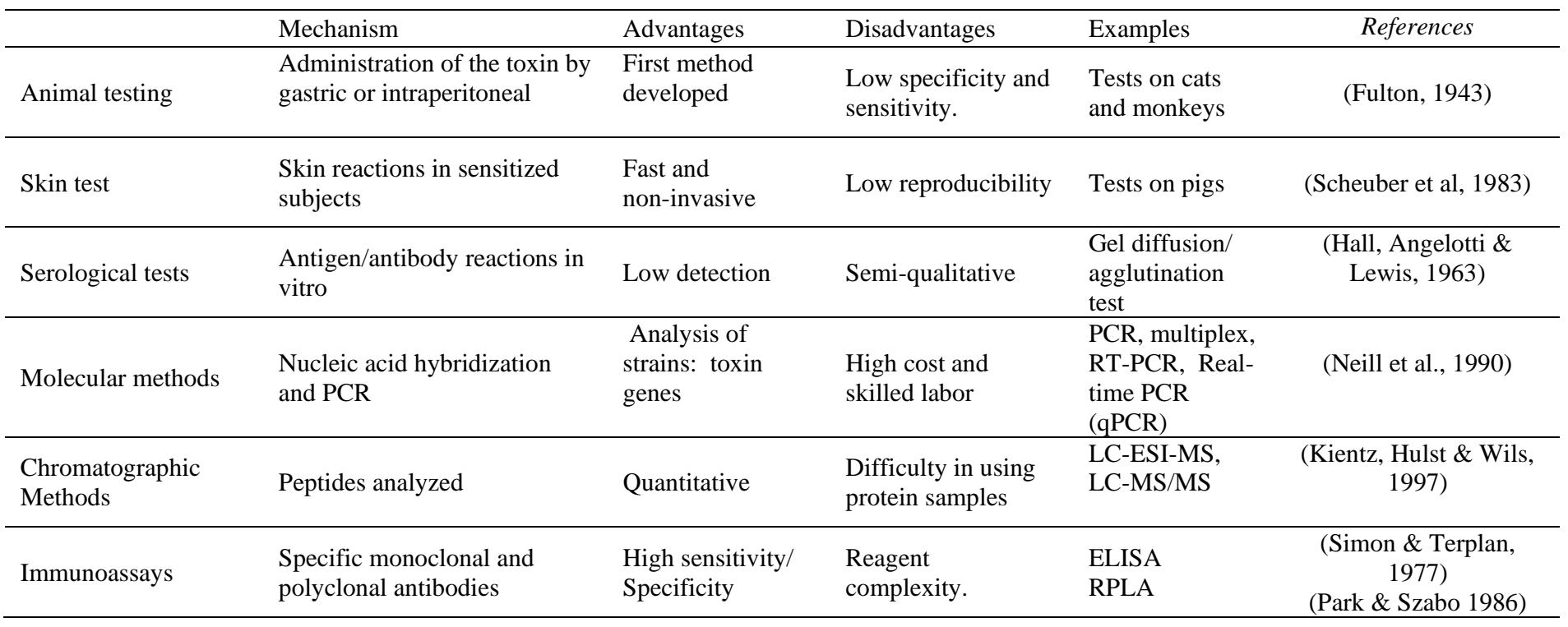

Source: Authors (2021).

The introduction of molecular biology techniques in microbiology has established a new era in the detection and characterization of microorganisms (Moreira et al., 2018). Molecular methods based on the Polymerase Chain Reaction (PCR) 
allow the detection of the nucleotide sequence of the gene, responsible for the production of enterotoxin by staphylococci. They are viable, fast methods widely used in gene research, requiring a small sample and applicable to a wide variety of foods: vegetables, milk, cheese, and meat products (Feitosa et al., 2017). Thus, it is possible to identify factors of pathogenesis, virulence and resistance to antibiotics, providing high sensitivity and specificity (Huertas-Caro et al., 2019).

Several S. aureus strains produce SE in food. Five classic SE (SEA, SEB, SEC, SED and SEE) are the most commonly found. In addition, 16 other types of SE or superantigens (SEG, SEH, SEI, SEJ, SEK, SEL, SEM, SEN, SEO, SEP, SEQ, SER, $S E S, S E T$, ITS and $S E V$ ) have also been described and evaluated, the main genes and targets of several studies are represented by sea, seb, sec, sed and see (Kim et al., 2011).

In general, conventional PCR is the technique most commonly used in the molecular diagnosis of different food pathogens, developed over 30 years ago (Mahfoozi et al., 2019). In SE analysis, PCR minimizes the time to detect and identify S. aureus that is difficult to recover, compared with the methods used previously.

Real-time PCR or Quantitative PCR (qPCR) assays are an evolution of PCR in which the step of evaluating products by agarose or polyacrylamide gel electrophoresis is eliminated. qPCR combines the amplification of specific DNA sequences with fluorophores with DNA affinity or fluorescent labeled probes. Different chemicals have been developed for the tagging of these probes, among the most important we find SYBR Green and hydrolysis probes (TaqMan) (Mahfoozi et al., 2019). DNA sequencing techniques can also be used to confirm gene sequences (Yehia et al., 2019).

Most instrumentation platforms consist of a thermocycler, with an optical system for excitation and collection of fluorescence emission and a computer with its own software for data acquisition and final reaction analysis (Mackay et al., 2007).

Multiplex PCR (PCRm), a conventional PCR variation, uses two or more pairs of primers in the same reaction, allowing the detection of more than one gene simultaneously. In 2017, Mansour and collaborators observed through this technique that strains of $S$. aureus encoded the see and sea genes in most samples of raw milk, warning of the potential risk of staphylococcal food poisoning.

Reverse transcriptase PCR (RT-PCR) allows expression studies, the amount of transcripts is correlated with the amount of SE produced, so the level of expression of SE genes could be used to assess the toxigenic potential in different isolates. Both PCRm and RT-PCR can be adapted to qPCR and these techniques are now called qPCRm and qRT-PCR, which adds benefits already mentioned above. PCR also has the advantage of being combined with other techniques, such as the most probable number (MPN-PCR) and enzyme immunoassay (PCR-ELISA) which can provide more sensitive results (Gillian et al., 2000).

\section{Final Considerations and Perspectives}

The presence of S. aureus in food, especially in milk and its derivatives, can cause several diseases. These diseases have the potential to cause millionaire losses to the dairy industry, which can cause loss of animals and products, in addition to harming consumers' health. Another industry that is very affected by the action of S. aureus is that of meat products, in which the effect of the formation of bacterial biofilm impairs the visual and nutritional quality of the final commercial product.

Advances in studies of more sensitive techniques that detect the presence of $S$. aureus or its enterotoxins in food are of great importance for the prevention of food poisoning outbreaks. Molecular techniques are promising in this detection, combined with maintaining the safety of the food industry and, consequently, human health.

But now? What are we going to expect? New treatments are constantly emerging and, as mentioned before, they tend to continue prioritizing good sanitary practices and biotechnological processes, which them hinder the fixation and growth of microorganisms directly in the body of animal or on the surface of food products. As a result of this global effort, it is expected 
that diseases caused by S. aureus or their enterotoxins are less frequently associated with different food production chains.

\section{Acknowledgments}

To Coordination for the Improvement of Higher Education Personnel (CAPES - Brazil) for the scholarships; to Universidade Federal do Rio Grande do Norte (UFRN), Universidade Federal do Ceará (UFC), Universidade Federal do Piauí (UFPI) and to Universidade Federal da paraíba (UFPB), Paraiba, for being of great importance for the execution of the research.

\section{References}

Akbas, M. Y., \& Kokumer, T. (2015). The prevention and removal of biofilm formation of Staphylococcus aureus strains isolated from raw milk samples by citric acid treatments. Int. J. Food Sci. 50, 1666-1672.

Aragão, B. B., Trajano, S. C., Silva, J. G., Silva, B. P., Oliveira, R. P., Junior, J. W. P., Peixoto, R. M., \& Mota, R. A. (2019). Short communication: High frequence of $\beta$-lactam-resistant Staphylococcus aureus in artesanal coalho cheese made from goat milk produced in northeastern Brazil. JDS. 102 , 6923-6927.

Basti, A. A., Misaghi, A., \& Khaschabi, D. (2007). Growth response and modeling of the effects of Zataria multiflora Boiss. Essential oil, pH and temperature on Salmonella typhimurium and Staphylococcus aureus. LWT. 40, 973-981.

Becker, T. A., Negrelo, I. F., Racoulte, F., \& Drunkler, D. A. (2010). Avaliação da qualidade sanitária de leite integral informal, pasteurizado, UHT e em pó comercializados na cidade de Medianeira e Serranópolis do Iguaçu - Paraná. Semina: Ciências Agrárias. 31, 707-716.

Chen, N., Chang, C. C., NG, C. C., Wang, C. Y., Shyu, Y. T., \& Chang, T. L. (2008). Antioxidant and antimicrobial activity of Zingiberaceae plants in Taiwan. Plant Foods Hum. Nutr. 63, 15-20.

Chiang, Y. C., Chang, L. T., Lin, C. W., Yang, C. Y., \& Tsen, H. Y. (2006). PCR primers for the detection of Staphylococcal enterotoxins K, L, and M and survey of Staphylococcal enterotoxin types in Staphylococcus aureus isolates from food poisoning cases in Taiwan. J. Food Prot. 69,1072-1079.

Cruz, A., Corassin, C. H., Oliveira, C., \& Zacarchenco, P. Processamento de Leites de Consumo. (2a ed.), Elsevier Editora Ltda, 2017. 384 p.

Damaceno, M. N., Bandeira, M. G. L., Silva, J. A., Costa, W. R. S., Gomes, J. S., Oliveira, V. M. S., Paiva, W. S., \& Souza Neto, F. E. (2014). Aplicação de nisina como revestimento comestível em queijo coalho. Revista Saúde e Ciência Online. 2014; 3, 297-304.

Denis, M., Wedlock, D. N., Lacy-Hulbert, S. J., Hillerton, J. E., \& Buddle, B. M. (2009). Vaccines against bovine mastitis in the New Zealand context: What is the best way forward? NZ Vet J. 57, 132-140.

Detilleux, J. C. (2009). Genetic factors affecting susceptibility to udder pathogens. Veterinary Microbiology. 134, $157-164$.

Erhabor, C. R., Erhabor, J. O., \& Mcgawa, L. J. (2019). The potential of South African medicinal plants against microbial biofilm and quorum sensing of foodborne pathogens: A review. S. Afr. J. Bot. 126, 214-231.

Feitosa, A. C., Rodrigues, R. M., Torres, E. A. T., \& Silva, J. F. M. (2017). Staphylococcus aureus em alimentos. Revista Desafios. 4, 15-31.

Ferreira, R., \& Simm, E. M. (2012). Análise microbiológica da carne moída de um açougue da região central do município de Pará de Minas/MG. SynThesis Revista Digital FAPAM. 3, 37-61.

Fulton, F. (1943). Staphylococcal Enterotoxin—with Special Reference to the Kitten Test. Br. J. Exp. Pathol. $24,65-72$.

Fuster-Valls, N., Hernández-Herrero, M., Marín-de-Mateo, M., Rodríguez-Jerez, J. J. (2008). Effect of different environmental conditions on the bacteria survival on stainless steel surfaces. Food Control. 19, 308-314.

Gallo, M., Ferrara, L., Calogero, A., Montesano, D., \& Naviglio, D. (2020). Relationships between food and diseases: What to know to ensure food safety. Int. Food Res. J.. 137, 109414.

Ghani, S., Barzegar, H., Noshad, M., \& Hojjati, M. (2018). The preparation, characterization and in vitro application evaluation of soluble soybean polysaccharide films incorporated with cinnamon essential oil nanoemulsions. Int. J. Biol. Macromol. 112, $197-202$.

Gilligan, K., Shipley, M., Stiles, B., Hadfield, T., \& Ibrahim, M. S. (2000). Identification of Staphylococcus aureus enterotoxins A and B genes by PCRELISA. Mol Cell Probes. 14, 71-78.

Goulart, A. E. R., Lacerda, I. C. A., \& Dias, R. S. (2016). Potencial risco de intoxicação alimentar por Sthaphtlococcus spp. enterotoxigênicos isolados de bolos com cobertura e recheio. NBC. $6,11-17$.

Hall, H. E., Angelotti, R., \& Lewis, K. H. (1963). Quantitative detection of Staphylococcal enterotoxin B in food by gel-diffusion methods. Public Health Rep. 78, 1089-1098.

Hennekinne, J. A., De Buyser, M. L., \& Dragacci, S. (2012). Staphylococcus aureus and its food poisoning toxins: characterization and outbreak investigation. FEMS Microbiology Review. 36, 815-36. 
Holmberg, S. D., \& Blake, P. A. (1984). Staphylococcal food poisoning in the United States: new facts and old misconceptions. JAMA. 251, 487-489.

Huertas-Caro, C., Urbano-Caceres, E., \& Torres-Caycedo, M. (2019). Diagnóstico molecular una alternativa para la detección de patógenos en alimentos. Rev. Habanera Cienc. Med. 18, 513-528.

Kientz, C. E., Hulst, A. G., \& Wils, E. R. (1997). Determination of Staphylococcal enterotoxin B by on-line (micro) liquid chromatography-electrospray mass spectrometry. J. Chromatogr. A. 757, 51-64.

Kim, N. H., Yun, A. R., \& Rhee, M. S. (2011). Prevalence and classification of toxigenic Staphylococcus aureus isolated from refrigerated ready-to-eat foods (sushi, kimbab and California rolls) in Korea. J. Appl. Microbiol. 111, 1456-1464.

Lancette, G. A., \& Bennett, R. W. Staphylococcus aureus and Staphylococcal Enterotoxins. In: F. P. Downes and K. Ito (eds.), Compendium of Methods for the Microbiological Examination of Foods. American Public Health Association; Washington, D.C., p. 387-403; 2001.

Le Roux, Y., Laurent, F., \& Moussaoui, F. (2003). Polymorphonuclear proteolytic activity and milk composition change. Veterinary Research, $34,629-645$.

Lima, E. S. C., Pinto, P. S. A, Santos J. L., Vanetti, M. C. D., Bevilacqua, P. D., Almeida, L. P., Mayara, S., Pinto, M. S., \& Dias, F. S. (2004). Isolamento de Isolamento de Salmonella Salmonella sp e Staphylococcus aureus Staphylococcus aureus no processo do abate suíno como subsídio ao sistema de processo do abate suíno como subsídio ao sistema de Análise de Perigos e Pontos Críticos de Controle - APPCC. Pesquisa Veterinária Brasileira. 24, 185-190.

Liyanage, C. J. (2020). Chapter 2 - Traditional and ethnic foods of Sri Lanka-safety aspects, Editor(s): Jamuna Prakash, Viduranga Waisundara, Vishweshwaraiah Prakash. In Nutritional \& Health Aspect-Traditional \& Ethnic Food, Nutritional and Health Aspects of Food in South Asian Countries, Academic Press, 2020, p. 127-141.

Mackay, I. M., Mackay, J. F., Nissen, M. D., \& Sloots, T. P. Real-time PCR; History and Fluorgenic Chemistries. Real-Time PCR in Microbiology From diagnosis to characterization. Edited by Mackay, I. M.. Horizon Press - Calister Academic Press.1-40. 2007.

Mahfoozi, A., Shirzad-Aski, H., Kaboosi, H.,Ghaemi, E. A. (2019). Identification of the classical enterotoxin genes of Staphylococcus aureus in various foods by multiplex PCR assay. Iran. J. Vet. Res. 20, 209-212.

Marchi, G. P., Junior, R. D. O., Cereser, D. N., Souza, V., Rezende, M. C. N., \& Faria, A. A. (2012). Avaliação microbiológica e físico-química da carne bovina moída comercializada em supermercados e açougues de Jaboticabal - SP. Revista Eletrônica da Univar. 7,81 - 87.

Martin, M., Fueyo, J., Gonzálezhevia, M., \& Mendoza, M. C. (2004). Genetic procedures for identification of enterotoxigenic strains of Staphylococcus aureus from three food poisoning outbreaks. Int. J. Food Microbiol. 94, 279-286.

Montanhini, M. T. M., \& Hein, K. K. (2013). Qualidade do leite cru comercializado informalmente no município de Piraí do Sul, Estado do Paraná, Brasil. Revista do ILCT. 68, 10-14.

Moreira, B. S., Azola, J. S. M., \& Gouvêa, C. M. C. P. (2018). Marcadores moleculares para identificação e caracterização do potencial patogênico de Escherichia coli e Staphylococcus aureus. SaBios. 13, 41-52.

Motta, R. G., Nardi Junior, G., Perrotti, I. B. M., \& Ribeiro, M. G. (2011). Mastite infecciosa equina: uma visão geral da doença. Arq. Inst. Biol. 78: 629-635.

Pola, C. C., Medeiros, E. A. A., Pereira, O. L., Souza, V. G. L., Otoni, C. G., Camilloto, G. P., \& Soares, N. F. F. (2016). Cellulose acetate active films incorporated with oregano (Origanum vulgare) essential oil and organophilic montmorillonite clay control the growth of phytopathogenic fungi. Food Packag. Shelf Life. 9, 69- 78.

Neill, R. J., Fanning, G. R., Delahoz, F., Wolff, R., \& Gemski, P. (1990). Oligonucleotide probes for detection and differentiation of Staphylococcus aureus strains containing genes for enterotoxins A, B, and C and toxic shock syndrome toxin 1. J. Clinical Microbiol. 28, $1514-1518$.

Park, C. E., \& Szabo, R. (1986). Evaluation of the reversed passive latex agglutination (RPLA) test kits for detection of staphylococcal enterotoxins A, B, C, and D in foods. Can. J. Microbiol. 32, 723-727.

Pranoto, Y., Rakshit, S. K., \& Salokhe, V. M. (2005). Enhancing antimicrobial activity of chitosan films by incorporating garlic oil, potassium sorbate and nisin. $L W T, 38,859-865$.

Sá, J. F. O., Martins, M. F., \& Silva, P. H. F. (2012). Caracterização microbiológica de doce de leite, leite condensado e queijo Minas padrão por metodológiaclássica e padronizaçãode multiplex pata detecção de patógenos por pcr em tempo real. Revista do ILCT. 67, 77-78.

Santos, M. V., \& Fonseca, L. F. L. Estratégias para o controle da mastite e melhoria da qualidade do leite. Barueri: Manole, 2006.314 p.

Santos, J. C. P., Sousa, R. C. S., Otoni, C. G., Moraes, A. R. F., Souza, V. G. L., Medeiros, E. A. A., Espitia, P. J. P., Pires, A. C. S., Coimbra, J. S. R., \& Soares, N. F. F. (2018). Nisin and other antimicrobial peptides: Production, mechanisms of action, and application in active food packaging. Innov Food Sci Emerg Technol. 48, 179-194.

Scheuber, P. H., Mossmann, H., Beck, G., \& Hammer, D. K. (1983). Direct skin test in highly sensitized guinea pigs for rapid and sensitive determination of staphylococcal enterotoxin B. Appl. Environ. Microbiol. 46, 1351-1356.

Simon, E., Terplan, G. (1977). Nachweis von Staphylokokken Enterotoxin B mittels ELISA-Test. Zentralblatt für Veterinärmedizin Reihe B. $224,842-844$.

Tozzetti, D. S., Bataier, M. B. N., Almeida, L. R., \& Piccinin, A. (2008). Prevenção, controle e tratamento das mastites bovinas-revisão de literatura. Revista Científica Eletrônica de Medicina Veterinária. 6, 1-7.

Wong, A. C. L., \& Bergdoll, M. S. Staphylococcal food poisoning. In: Cliver, DO, Riemann HP. Foodborne Diseases . Amsterdam: Academic Press, p. 231 $248 ; 2002$. 
Research, Society and Development, v. 10, n. 14, e372101422186, 2021

(CC BY 4.0) | ISSN 2525-3409 | DOI: http://dx.doi.org/10.33448/rsd-v10i14.22186

Yehia, H. M., Al-Masoud, A. H., Alsawmahi, O. N., Aljahani, A. H., \& El-Din, M. F. S. (2020). Effects of citrox treatment on the survival of MethicillinResistant taphylococcus aureus (MRSA) in chicken fillets packed under vacum. Food Sci. Technol. 40, 588-595.

Yehia, H. M., Ismail, E. A., Hassan, Z. K., Al-Masoud, A. H., \& Al-Dagal, M. M. (2019). Heat resistance and presence of genes encoding staphylococcal enterotoxins evaluated by multiplex-PCR of Staphylococcus aureus isolated from pasteurized camel milk. Biosci. Rep. 39, BSR20191225.

Zhang, Y., Xu, D., Shi, L., Cai, R, Li, C, \& Yan, H. (2018). Association between agr type, virulence factors, biofilm formation and antibiotic resistance of Staphylococcus aureus isolates from pork production. Front Microbiol. 9, 1-12. 